\title{
Karakteristik Keluarga ODGJ dan Kepesertaan JKN Hubungannya dengan Tindakan Pencarian Pengobatan bagi ODGJ
}

\author{
Dewi Norma Palupi ${ }^{1}$, Mury Ririanty ${ }^{1}$, Iken Nafikadini ${ }^{1}$ \\ Fakultas Kesehatan Masyarakat Universitas Jember, Indonesia ${ }^{1}$ \\ e-mail:dpalupi08@gmail.com
}

\begin{abstract}
The mental health issue in Indonesia still become a very important concern from various sectors either government or society. The absent finacial abilities result to the delay of mental illness patient treatment. Some various rules have been issued for dealing these mental illness issues, among them were including the National Health Insurance (JKN). The family has an important role as a health service within particular unit, because the health problems which emerged within the family will contagiously affect another family members and its environment. The existence of the keluarga ODGJt's characteristic will determine the ODGJ in the treatment seeking action. The purpose of this study to determine the relationship between keluarga ODGJts and JKN membership with action for ODGJ treatment in Puger sub-district of Jember regency. This type of research is quantitative with descriptive approach. The results of this study indicate that there is a relationship between the characteristics of the keluarga ODGJt (education) withacts of seeking ODGJ treatment, and also there are no relationship between the characteristic of keluarga ODGJts (type, sex, occupation, income, sick parents, family, kinship, family type) and National Health with acts of seeking ODGJ treatment.
\end{abstract}

Keywords: characteristics of keluarga ODGJ, family, JKN, ODGJ, treatment

\section{Pendahuluan}

Gangguan jiwa adalah sindrom pola perilaku seseorang yang secara khas berkaitan dengan suatu gejala penderitaan (distress) atau hendaya (impairment) di dalam satu atau lebih fungsi yang penting dari manusia, yaitu fungsi psikologik, perilaku, biologik, dan gangguan itu tidak hanya terletak di dalam hubungan antara orang itu tetapi juga dengan masyarakat (Yusuf, A.H., Rizky, F., dan Hanik, E.N. 2015).Orang Dengan Gangguan Jiwa yang selanjutnya disebut ODGJ adalah seseorang yang mengalami gangguan dalampikiran, perilaku dan perasaan yang termanifestasi dalam bentuk sekumpulan gejala dan atau perubahan perilaku yang bermakna, serta dapat menimbulkan penderitaan dan hambatan dalam menjalankan fungsi sebagai manusia (Undang-Undang Nomor 18 Tahun 2014). Oleh karena itu gangguan jiwa ini masih menjadi perhatian yang sangat penting dari berbagai lintas sektor baik pemerintah maupun masyarakat, hal ini dikarenakan gangguan jiwa menghabiskan biaya pelayanan kesehatan yang besar (Kementerian Kesehatan Republik Indonesia, 2013).

Riset Kesehatan Dasar tahun 2013 menunjukkan prevalensi gangguan mental emosional yang ditunjukkan dengan gejala- gejala depresi dan kecemasan adalahsebesar $6 \%$ untuk usia 15 tahun ke atas atau sekitar 14 juta orang. Sedangkan prevalensi gangguan jiwa berat seperti skizofrenia adalah 1,7 per 1000 penduduk atau sekitar 400.000 orang (Kementerian Kesehatan Republik Indonesia, 2014). Prevalensi gangguan jiwa di Indonesia bervariasi pada masing masing Provinsi. Pada hal ini, Jawa Timur menduduki peringkat keempat dengan prevalensi gangguan jiwa tertinggi yaitu dengan angka 2,2\%o penduduk (Kementerian Kesehatan Republik Indonesia, 2014)

Kabupaten Jember merupakan salah satu Kabupaten di Jawa Timur yang telah menerapkan SPM (Standar Pelayanan Minimum) yang direalisasikan dalam bentuk pelayanan promotif dan preventif dan mengadakan pelayanan kesehatan jiwa di Puskesmas (Dinas Kesehatan Kabupaten Jember 2016). Kecamatan Puger merupakan Kecamatan yang mempunyai prevalensi gangguan jiwa tertinggi di Kabupaten Jember. Berdasarkan hasil studi pendahuluan, ternyata di Puger terdapat 86 ODGJ dengan rincian 40 ODGJ terdaftar di Puskesmas Kasiyan, dan 46 ODGJ terdaftar di Puskesmas Puger.

Keluarga merupakan kelompok terkecil yang ada di lingkungan individu. Sebagai pembentuk sikap dan kepribadian, 
keluarga mempunyai peran yang penting sebagai pelayanan kesehatan di dalam unit terkecil. Usaha keluarga untuk pelaksanaan pengobatan pada orang dengan gangguan jiwa dilakukan pada pengobatan profesional yang berupa pil dan suntikan dari tenaga kesehatan, pengobatan non profesional yang berupa dukun dan kyai, serta penanganan sendiri yang berupa meminumkan pil yang dibeli sendiri (Halida, N., Dewi, E. I., Rasni, H. 2016).

Adanya program bebas pasung, program GERMAS indikator ke-8 dan Undang-Undang Nomor 18 Tahun 2014 yang mengatur kesehatan jiwa akan membantu meningkatkan kesehatan jiwa yang ada di masyarakat (Kementerian Kesehatan Republik Indonesia, 2017).Peraturan Presiden Nomor 12 Tahun 2013 Tentang Jaminan Kesehatan juga menyebutkan bahwa kepesertaan Jaminan Kesehatan Nasional bersifat wajib bagi seluruh penduduk Indonesia dan dapat digunakan untuk pengobatan orang dengan gangguan jiwa.

Kurangnya pengetahuan keluarga
terkait pengobatan ODGJ membuat penanganannya terlambat, hal ini disebabkan karena minimnya pengetahuan terhadap akses pelayanan kesehatan jiwa, serta adanyaanggapan masyarakat bahwa penyakit kejiwaan dianggap sebagai kutukan dari Tuhan, hukuman atas dosa di kehidupan masa lalu, atau manifestasi dari roh-roh jahat (Lestari,W., dan Wardhani, Y.F., 2014). Belum berhasilnya pengobatan juga disebabkan Ketiadaan biaya membuat pengobatan ODGJ ke pelayanan kesehatan dihentikan. Hal itu dikarenakan biaya yang telah dikeluarkan pada pengobatan ODGJtidak terlihat hasilnya pada kesembuhannya (Halida, N., Dewi, E. I., Rasni, H, 2016). Selain itu keadaan ekonomi keluarga dari kalangan menengah kebawah sehingga menyebabkan keluarga berfikir bahwa pengobatan secara non medis ke kyai atau dukun mudah dilakukan dan tidak memerlukan biaya yang tinggi.

Peneliti menggunakan teori Lawrence Green yang memaparkan adanya peran karakteristik keluarga ODGJ (usia, jenis kelamin, pendidikan, jenis pekerjaan, pendapatan keluarga, lama sakit anggota keluarga, hubungan kekerabatan, dan tipe keluarga), serta kepesertaan Jaminan Kesehatan Nasional. Karakteristik keluarga ODGJ dapat menentukan seseorang dalam bertindak, dan dengan adanya kepesertaan Jaminan Kesehatan Nasional akan mendukung pencarian pengobatan bagi orang dengan gangguan jiwa (ODGJ).Berdasarkan hal tersebut peneliti tertarik untuk meneliti hubungan karakteristik keluarga ODGJ dan kepesertaan Jaminan Kesehatan Nasional dengan tindakan pencarian pengobatan ODGJ di Kecamatan Puger Kabupaten Jember.

\section{Metode}

Penelitian kuantitatif dengan pendekatan deskriptif. Dilakukan di Kecamatan Puger, Kabupaten Jember pada bulan Maret 2018-Mei 2018.Variabel penelitian ini adalah tindakan pencarian pengobatan bagi ODGJ dan karakteristik keluarga ODGJ (usia, jenis kelamin, pendidikan, jenis pekerjaan, pendapatan, lama sakit anggota keluarga, hubungan kekerabatan, tipe keluarga) dan kepesertaan Jaminan Kesehatan Nasional, Populasi yang diambil adalah keluarga dekat yang merawat ODGJ di Kecamatan Puger Kabupaten Jember yang terdaftar di wilayah kerja Puskesmas Kasiyan dan Puskesmas Puger. Sampel di tentukan menggunakan proportional sample, didapatkan sampel sebanyak 46 keluarga ODGJ.

\subsection{Metode Pengumpulan Data}

Data diperoleh melalui wawancara terstruktur dan data sekunder dari Dinas Kesehatan Kabupaten Jember, Dinas Sosial Kabupaten Jember, Puskesmas Puger, Puskesmas Kasiyan. Wawancara menggunakan lembar panduan wawancara.

\subsection{Metode Analisis Data}

Analisis data menggunakan analisis univariat dan bivariat.dengan uji statistik $\mathrm{Chi}$ square, alpha 0,05.

\section{Hasil dan Pembahasan}

Hasil penelitian ini meliputi hasil analisis univariate dan bivariate. Tabel 1 menunjukkan distribusi karakteristik keluarga ODGJ.

Tabel 1. Distribusi Karakteristik Keluarga ODGJ 
ISSN 2354-5852

E-ISSN 2579-5783

\begin{tabular}{|c|c|c|}
\hline $\begin{array}{c}\text { Karakteristik Keluarga } \\
\text { ODGJ } \\
\end{array}$ & $\mathbf{N}$ & $\%$ \\
\hline \multicolumn{3}{|l|}{ Usia } \\
\hline$\leq 30$ Tahun & 4 & 8,7 \\
\hline$>30$ Tahun & 42 & 91,3 \\
\hline Total & 46 & 100 \\
\hline \multicolumn{3}{|l|}{ Jenis Kelamin } \\
\hline Laki-laki & 19 & 41,3 \\
\hline Perempuan & 27 & 58,7 \\
\hline Total & 46 & 100 \\
\hline \multicolumn{3}{|l|}{ Pendidikan } \\
\hline Dasar & 41 & 89,1 \\
\hline Menengah & 5 & 10,9 \\
\hline Tinggi & 0 & 0 \\
\hline Total & 46 & 100 \\
\hline \multicolumn{3}{|l|}{ Jenis Pekerjaan } \\
\hline Tidak bekerja & 2 & 4,3 \\
\hline Bekerja & 44 & 95,7 \\
\hline Total & 46 & 100 \\
\hline \multicolumn{3}{|l|}{ Pendapatan } \\
\hline$<$ Rp.1.916.983,99 & 44 & 95,7 \\
\hline$\geq$ Rp.1.916.983,99 & 2 & 4,3 \\
\hline Total & 46 & 100 \\
\hline \multicolumn{3}{|l|}{ Lama Sakit Anggota } \\
\hline \multicolumn{3}{|l|}{ Keluarga } \\
\hline$\leq 1$ tahun & 1 & 2,2 \\
\hline$>1$ tahun & 45 & 97,8 \\
\hline Total & 46 & 100 \\
\hline
\end{tabular}

dari separuh keluarga ODGJ memiliki pekerjaan dengan persentase 95,7\%. Hampir seluruh keluarga ODGJ memiliki pendapatan kurang dari Rp.1.916.983,99 dengan persentase 95,7\%. Hampir seluruh keluarga ODGJ menyatakan bahwa lama sakit anggota keluarga lebih dari 1 tahun dengan persentase $97,8 \%$. Hubungan kekerabatan keluarga ODGJ yaitu sebagai ayah, ibu, suami, anak, saudara kandung dan saudara ipar. Lebih dari separuh keluarga ODGJ memiliki hubungan kekerabatan dengan penderita gangguan jiwa yaitu sebagai anak dengan persentase $67,4 \%$. Lebih dari separuhkeluarga ODGJ memiliki tipe keluarga dengan penderita gangguan jiwa yaitu keluarga inti sebesar $67,4 \%$. Tabel 2 menunjukkan distribusi kepesertaan Jaminan Kesehatan Nasional

Tabel 2. Distribusi Kepesertaan Jaminan Kesehatan Nasional

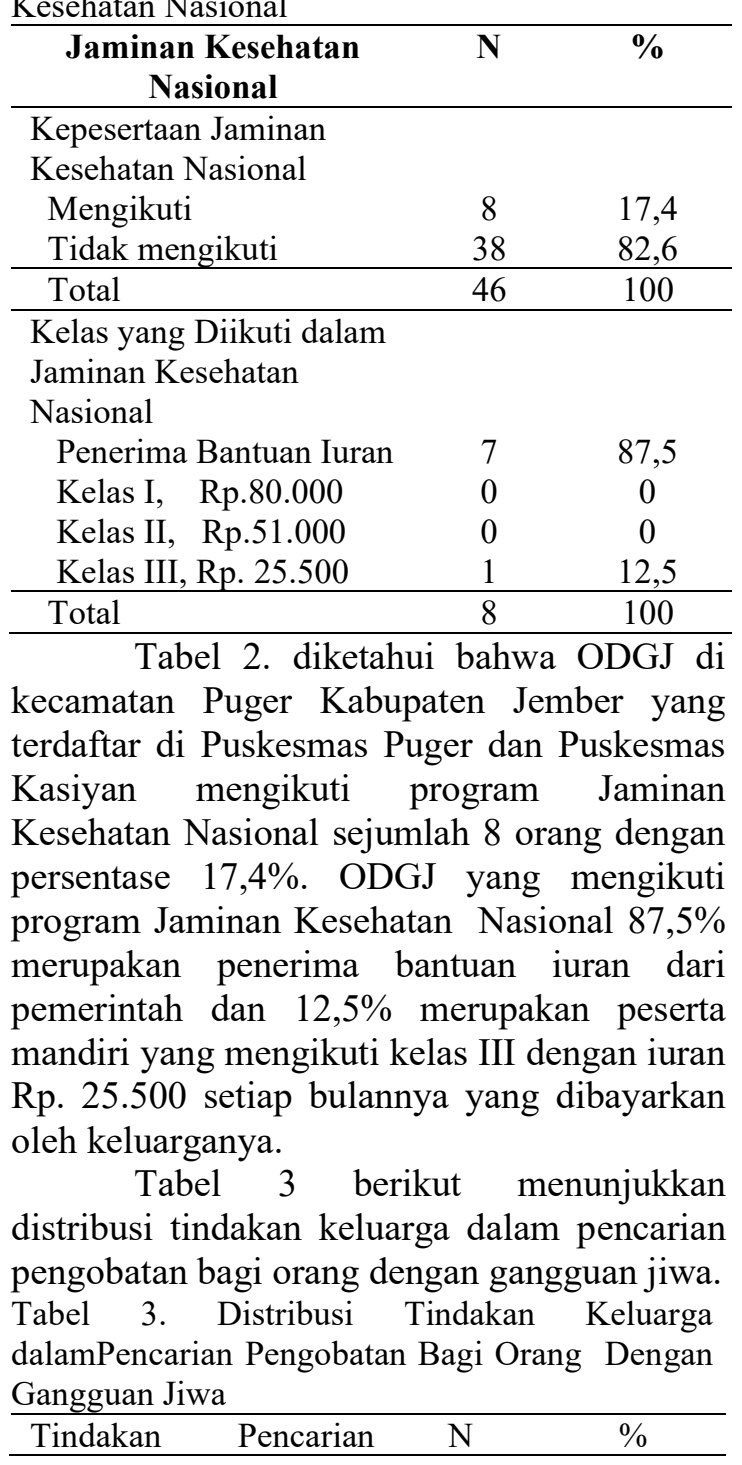




\begin{tabular}{|c|c|c|}
\hline Pengobatan & & \\
\hline Sesuai & 21 & 45,7 \\
\hline Tidak Sesuai & 25 & 54,3 \\
\hline Total & 46 & 100 \\
\hline
\end{tabular}

keluarga dalam pencarian pengobatan bagi ODGJ di Kecamatan Puger Kabupaten Jember. Lebih dari separuh keluarga ODGJ mempunyai tindakan yang tidak sesuai sebesar $54,3 \%$ dan tindakan yang sesuai sebesar $45,7 \%$. Berikut ini merupakan tabel yang berisikan tindakan pencarian pengobatan keluarga ODGJ bagi ODGJ. Berikut merupakan tabel deskripsi tindakan pencarian pengobatan bagi orang dengan gangguan jiwa (ODGJ).

Tabel 4. Deskripsi Tindakan PencarianPengobatan Bagi Orang Dengan Gangguan Jiwa (ODGJ)

\begin{tabular}{|c|c|c|c|c|}
\hline $\begin{array}{c}\text { Tindakan } \\
\text { Pencarian } \\
\text { Pengobatan }\end{array}$ & Ya & $\%$ & Tidak & $\%$ \\
\hline \multicolumn{5}{|l|}{ Tidak Sesuai } \\
\hline $\begin{array}{l}\text { Tidak melakukan } \\
\text { tindakan apa-apa } \\
\text { Mengobati sendiri } \\
\text { dengan cara: }\end{array}$ & 0 & 0 & 46 & 100 \\
\hline dipasung & 39 & 84,8 & 7 & 15,2 \\
\hline $\begin{array}{l}\text { dibacakan doa- } \\
\text { doa/diruqyah }\end{array}$ & 33 & 71,7 & 13 & 28,3 \\
\hline $\begin{array}{l}\text { dimandikan } \\
\text { bunga }\end{array}$ & 8 & 17,4 & 38 & 82,6 \\
\hline $\begin{array}{l}\text { menyembelih } \\
\text { ayam yang telah } \\
\text { diberi do'a }\end{array}$ & 2 & 4,3 & 44 & 95,7 \\
\hline $\begin{array}{l}\text { Berobat ke } \\
\text { fasilitas-fasilitas } \\
\text { pengobatan } \\
\text { tradisional } \\
\text { seperti } \\
\text { tabib,dukun,kyai) }\end{array}$ & 45 & 97,8 & 1 & 2,2 \\
\hline $\begin{array}{l}\text { Membeli obat di } \\
\text { warung terdekat }\end{array}$ & 14 & 30,4 & 32 & 69,6 \\
\hline \multicolumn{5}{|l|}{ Sesuai } \\
\hline $\begin{array}{l}\text { Berobat ke fasilitas } \\
\text { pengobatan modern } \\
\text { seperti klinik, } \\
\text { Puskesmas, Rumah } \\
\text { Sakit) }\end{array}$ & 46 & 100 & 0 & 0 \\
\hline $\begin{array}{l}\text { Berobat ke Dokter } \\
\text { Praktik }\end{array}$ & 28 & 60,9 & 18 & 39,1 \\
\hline $\begin{array}{l}\text { Tabel 4.dik } \\
\text { keluarga ODGJ der } \\
\text { tidak ada yang tidal } \\
\text { separuh keluarga OI } \\
84,8 \% \text { melakukan }\end{array}$ & $\begin{array}{l}\text { ahui } \\
\text { gan }\end{array}$ & bal & se & $\begin{array}{l}\text { ruh } \\
0 \% \\
\text { lari } \\
\text { ase } \\
\text { an, }\end{array}$ \\
\hline
\end{tabular}

sebesar 71,7\% keluarga ODGJ melakukan pengobatan sendiri dengan caradibacakan doa-doa/ diruqyah, 17,4\% melakukan pengobatan sendiri dengan cara dimandikan bunga, 4,3\%keluarga ODGJmelakukan pengobatan sendiri dengan cara menyembelih ayam yang telah diberi doa-doa.Hampir seluruh keluarga ODGJ dengan persentase $97,8 \%$ mencari pengobatan ke fasilitaspengobatan tradisional yaitu berupa dukun,kyai. Sebesar 30,4\% keluarga ODGJ membeli obat di warung terdekat, $60,9 \%$ mencari pengobatan kedokter praktik dan seluruh keluarga ODGJ dengan persentase $100 \%$ melakukan tindakan pengobatan ke fasilitas pelayanan kesehatan modern berupa Puskesmas dan Rumah Sakit. Hasil tabulasi silang antara karakteristik keluarga ODGJ dengan tindakan pencarian pengobatan bagi orang dengan gangguan jiwa (ODGJ) disajikan dalam Tabel 5.

Tabel 5. Hasil Tabulasi Silang antara Karakteristik Keluarga ODGJ dengan Tindakan Pencarian Pengobatan Bagi Orang dengan Gangguan Jiwa (ODGJ)

\begin{tabular}{|c|c|c|c|c|}
\hline \multirow{3}{*}{$\begin{array}{c}\text { Karakteristik } \\
\text { Keluarga ODGJ }\end{array}$} & \multicolumn{4}{|c|}{ Tindakan } \\
\hline & \multicolumn{2}{|c|}{ Sesuai } & \multicolumn{2}{|c|}{$\begin{array}{l}\text { Tidak } \\
\text { Sesuai }\end{array}$} \\
\hline & $\mathbf{N}$ & $\%$ & $\mathbf{N}$ & $\%$ \\
\hline \multicolumn{5}{|l|}{ Usia } \\
\hline$\leq 30$ Tahun & 1 & 2,2 & 3 & 6,5 \\
\hline$>30$ Tahun & 20 & 43,5 & 22 & 47,8 \\
\hline$p$-value & & 0,732 & & \\
\hline \multicolumn{5}{|l|}{ Jenis Kelamin } \\
\hline Laki-Laki & 10 & 21,7 & 9 & 19,6 \\
\hline Perempuan & 11 & 23,9 & 16 & 34,8 \\
\hline$p$-value & & 0,619 & & \\
\hline \multicolumn{5}{|l|}{ Pendidikan } \\
\hline Dasar & 16 & 34,8 & 25 & 54,3 \\
\hline Menengah & 5 & 10,9 & 0 & 0 \\
\hline$p$-value & & 0,035 & & \\
\hline \multicolumn{5}{|l|}{ Jenis Pekerjaan } \\
\hline Bekerja & 19 & 41,3 & 25 & 54,4 \\
\hline Tidak Bekerja & 2 & 4,3 & 0 & 0 \\
\hline$p$-value & & 0,394 & & \\
\hline \multicolumn{5}{|l|}{ Pendapatan } \\
\hline$\geq$ Rp.1.916.983,99 & 2 & 4,3 & 0 & 0 \\
\hline$<$ Rp.1.916.983,99 & 19 & 41,3 & 25 & 54,4 \\
\hline$p$-value & & 0,394 & & \\
\hline
\end{tabular}




\begin{tabular}{lcccc}
\hline $\begin{array}{l}\text { Lama Sakit } \\
\text { Anggota Keluarga }\end{array}$ & & & & \\
\hline$\leq 1$ Tahun & 1 & 2,2 & 0 & 0 \\
$>1$ Tahun & 20 & 43,4 & 25 & 54,4 \\
\hline$p$-value & & 0,930 & &
\end{tabular}

Hubungan

Kekerabatan

\begin{tabular}{lcccc}
\hline Ayah & 1 & 2,2 & 0 & 0 \\
Ibu & 1 & 2,2 & 0 & 0 \\
Anak & 16 & 34,8 & 20 & 43,5 \\
Saudara & 2 & 4,3 & 3 & 6,5 \\
Kandung & & & & \\
Saudara Ipar & 1 & 2,2 & 2 & 4,3 \\
\hline$p$-value & & 0,340 & &
\end{tabular}

\begin{tabular}{|c|c|c|c|c|}
\hline \multicolumn{5}{|l|}{ Tipe Keluarga } \\
\hline Keluarga Inti & 14 & 30,4 & 17 & 37,0 \\
\hline Keluarga Besar & 7 & 15,2 & 8 & 17,4 \\
\hline$p$-value & & 1,000 & & \\
\hline
\end{tabular}

Tabel 5 menunjukkan bahwa tindakan keluarga dalam pencarian pengobatan yang sesuai lebih banyak dilakukan pada keluarga ODGJ yang berusia $>30$ tahun dengan persentase $43,5 \%$. Nilai $p$-value yang didapatkan sebesar $0,732(p>0,05)$. Nilai ini menunjukkan tidak terdapat hubungan yang signifikan antara usia dengan tindakan pencarian pengobatan bagi ODGJ dengan koefisien phi $\quad-0,128$.

Pada jenis kelamin, tindakan pencarian pengobatan yang sesuai lebih banyak pada keluarga ODGJ yang berjenis kelamin perempuan dengan persentase 23,9. Nilai p-value yang didapatkan sebesar 0,619 $(\mathrm{p}>0,05)$. Nilai ini menunjukkan tidak terdapat hubungan yang signifikan antara jenis kelamin keluarga ODGJ dengan tindakan pencarian pengobatan bagi orang dengan gangguan jiwa dengan koefisien phi 0,118.

Keluarga ODGJ yang melakukan tindakan tidak sesuai lebih banyak dilakukan pada keluarga ODGJ yang memiliki pendidikan dasar yaitu dengan persentase $54,3 \%$. Nilai $p$-value yang didapatkan sebesar $0,035 \quad(p<0,05)$. Nilai ini menunjukkan terdapat hubungan yang signifikan antara pendidikan keluarga ODGJ dengan tindakan pencarian pengobatan bagi Orang Dengan Gangguan Jiwa dengan koefisien phi 0,381 yang berarti berkorelasi. Tindakan keluarga dalam pencarian pengobatan yang tidak sesuai lebih banyak dilakukan keluarga ODGJ yang bekerja dengan persentase $54,4 \%$. Nilai $p$ value yang didapatkan sebesar $0,394(\mathrm{p}>0,05)$. Nilai ini menunjukkan tidak terdapat hubungan yang signifikan antara pekerjaan dengan tindakan pencarian pengobatan bagi orang dengan gangguan jiwa.

Tabel 6 berikut menunjukkan kepesertaan jaminan kesehatan nasional. Tabel 6. Kepesertaan Jaminan Kesehatan Nasional

\begin{tabular}{lcccc}
\hline \multirow{2}{*}{$\begin{array}{l}\text { Jaminan } \\
\text { Kesehatan }\end{array}$} & \multicolumn{4}{c}{ Tindakan } \\
\cline { 2 - 5 } Nasional & \multicolumn{3}{c}{ Sesuai } & \multicolumn{3}{c}{ Tidak Sesuai } \\
\cline { 2 - 5 } & $\mathbf{N}$ & \% & N & $\%$ \\
\hline Mengikuti & 4 & 8,7 & 4 & 8,7 \\
Tidak & 20 & 43,5 & 18 & 39,1 \\
Mengikuti & \multicolumn{4}{c}{1,000} \\
$p$-value & \multicolumn{4}{c}{} \\
\hline
\end{tabular}
Pada tabel 6. dapat diketahui bahwa tindakan keluarga dalam pencarian pengobatan yang sesuai lebih banyak dilakukan pada ODGJ yang tidak mengikuti kepesertaan Jaminan Kesehatan Nasional (JKN) dengan persentase 43,5\%. Sebesar $8,7 \%$ keluarga ODGJ melakukan tindakan pengobatan yang tidak sesuai pada ODGJ yang mempunyai Jaminan Kesehatan Nasional (JKN). Nilai p-value yang didapatkan sebesar 1,000 ( $>>0,05)$. Nilai ini menunjukkan tidak terdapat hubungan yang signifikan antara kepesertaan Jaminan Kesehatan Nasional (JKN) dengan tindakan pencarian pengobatan bagi orang dengan gangguan jiwa.

Keluarga ODGJ mempunyai tindakan pencarian pengobatan yang sesuai lebih banyak pada keluarga ODGJ dengan pendapatan $\geq 1.916 .983,99$ dengan persentase $4,3 \%$. Nilai $p$-value yang didapatkan sebesar $0,394(p>0,05)$. Nilai ini menunjukkan tidak terdapat hubungan yang signifikan antara pendapatan keluarga ODGJ dengan tindakan pencarian pengobatan bagi orang dengan gangguan jiwa.

Pencarian pengobatan yang tidak sesuai lebih banyak dilakukan keluarga ODGJpada ODGJ yang mempunyai lama sakit lebih dari 1 tahun dengan persentase $43,4 \%$. Nilai $p$-value yang didapatkan sebesar $0,930(p>0,05)$. Nilai ini menunjukkan tidak terdapat hubungan yang signifikan antara lama sakit ODGJ dengan tindakan pencarian pengobatan bagi orang dengan gangguan jiwa. 
Tindakan keluarga dalam pencarian pengobatan yang tidak sesuai lebih banyak dilakukan pada ODGJ yang mempunyai hubungan kekerabatan dengan keluarga ODGJ sebagai anak yaitu dengan persentase $43,5 \%$. Nilai $p$-value yang didapatkan sebesar 0,340 $(\mathrm{p}>0,05)$. Nilai ini menunjukkan tidak terdapat hubungan yang signifikan antara hubungan kekerabatan antara keluarga ODGJ dan ODGJ dengan tindakan pencarian pengobatan bagi orang dengan gangguan jiwa.

Pencarian pengobatan yang sesuai lebih banyak pada keluarga ODGJ dengan tipe keluarga inti dengan persentase $30,4 \%$. Nilai $p$-value yang didapatkan sebesar 1,000 $(\mathrm{p}>0,05)$. Nilai ini menunjukkan tidak terdapat hubungan yang signifikan antara tipe keluarga keluarga ODGJ dengan tindakan pencarian pengobatan bagi orang dengan gangguan jiwa.

\subsection{Hubungan Usia dengan Tindakan Pencarian Pengobatan Bagi ODGJ}

Usia merupakan ukuran yang dapat menggambarkan tingkat kedewasaan seseorang, karena semakin tinggi usia, maka pengetahuan merekapun bertambah, karena pengetahuan yang mereka dapatkan bukan hanya berasal dari lingkungan tingkat pendidikan, tetapi juga didapatkan dari pengalaman mereka menghadapi realita kehidupan menuju kematangan pemikiran (Sya'diyah, H, 2016). Usia yang diperoleh pada penelitian ini tidak berhubungan dengan tindakan pencarian pengobatan. Hal ini tidak sesuai dengan teori Lawrence green yang menyatakan bahwa tindakan seseorang akan dipengaruhi oleh usia (Notoatmodjo,S., 2012). Keluarga ODGJ mempunyai tindakan pencarian pengobatan yang sesuai lebih banyak pada keluarga ODGJ yang memiliki usia $>30$ tahun. Tindakan pencarian pengobatan yang dilakukan pada keluarga ODGJ yang berusia $>30$ tahun ini dipengaruhi oleh pengalaman dan pengetahuan yang didapatkan oleh keluarga ODGJ. Seseorang yang mempunyai usia diatas 30 tahun cenderung untuk mencarikan pengobatan keluarganya secara optimal ke pelayanan kesehatan daripada pengobatan tradisional, hal ini dikarenakan adanya pengalaman yang kurang baik terhadap pengobatan tradisional (Supriadi, 2014).
Pada penelitian ini walaupun keluarga ODGJ berusia $>30$ tahun tetapi jika mereka tidak mempunyai pengetahuan yang baik dan tidak mendapatkan pengalaman yang cukup dalam pencarian pengobatan, maka keluarga ODGJ juga akan melakukan tindakan yang tidak sesuai. Keluarga ODGJ yang berusia $\leq 30$ tahun ada yang melakukan tindakan yang sesuai, hal ini diakibatkan pengetahuan keluarga ODGJ terkait ODGJ sudah baik yang didapatkan dari sosialisasi yang pernah dilakukan olehpetugas kesehatan. Selain itu, hal-hal yang pernah didapatkan dari masa lalu dalam pencarian pengobatan maka akan membentuk tindakan seseorang (Waskitho, A.P. 2015).

\subsection{Hubungan Jenis Kelamin dengan Tindakan Pencarian Pengobatan Bagi ODGJ}

Jenis kelamin merupakan salah satu yang faktor yang mempengaruhi seseorang dalam pengambilan keputusan. Seorang kepala keluarga laki-laki biasanya lebih dominan dalam pengambilan keputusan. Tetapi jika yang ada hanya perempuan, maka perempuan tersebut juga bisa mengambil keputusan untuk anggota keluarganya (Supriadi, 2014). Pada penelitian ini jenis kelamin tidakberhubungan dengan pencarian pengobatan. Hal ini dikarenakan kemampuan keluarga ODGJ dalam menentukan keputusan dalam pencarian pengobatan telah didasari oleh pengalaman dan pengetahuan yang didapatkan mengenai gangguan jiwa. Keluarga ODGJ yang berjenis kelamin lakilaki belum tentu memperoleh pengetahuan dan pengalaman yang baik, sehingga jenis kelamin tidak mempengaruhi dalam pencarian pengobatan yang dilakukan oleh keluarga ODGJ. Hasil yang didapatkan peneliti tidak sesuai dengan teori Lawrence green yang menyatakan bahwa tindakan seseorang akan dipengaruhi oleh jenis kelamin (Notoatmodjo,S., 2012). Adanya emansipasi wanita akan mendorong perempuan dalam pengambilan keputusan sehingga keputusan yang diambil tidak bergantung pada seorang laki-laki (Supriadi, 2014). Selain itu tindakan seseorang juga didasari konsep sehat sakit dan pengetahuan terkait sakit yang diderita keluarga sehingga jenis kelamin seseorang 
tidak dapat mempengaruhi dalam tindakannya (Sya'diyah, H. 2016)

\subsection{Hubungan Pendidikan dengan Tindakan Pencarian Pengobatan Bagi ODGJ}

Pendidikan diperlukan untuk mendapatkan informasi yang menunjang kesehatan, sehingga dapat meningkatkan kualitas hidup seseorang. Semakin tinggi tingkat pendidikan seseorang maka akan semakin mudah menerima informasi sehingga semakin banyak pula pengetahuan yang dimiliki. Pada penelitian ini didapatkan hubungan antara tingkat pendidikan keluarga ODGJ dengan tindakan pencarian pengobatan bagi Orang Dengan Gangguan Jiwa (ODGJ).

Sebagian besar keluarga ODGJ yang memiliki pendidikan dasar tindakan pencarian pengobatan yang dilakukan tidak sesuai, dan seluruh keluarga ODGJ yang memiliki tingkat pendidikan menengah memiliki tindakan pencarian pengobatan yang sesuai. Tindakan pencarian pengobatan yang tidak sesuai dikarenakan keluarga ODGJ lebih banyak melakukan tindakan pengobatan kepada selain tindakan medis, yaitu seperti pergi ke dukun, kyai, mengobati sendiri dengan cara memandikan dengan air bunga, disembelihkan ayam, menggelar selamatan dengan doadoa/diruqyah, di pasung/di rantai dan membeli obat di warung terdekat.

Pengobatan yang dilakukan pada pengobatan non medis tidak sesuai, karena gangguan jiwa disebabkan karena adanya gangguan keseimbangan zat kimia (neurotransmiter), oleh karena itu pengobatan gangguan jiwa dapat dilakukan sesuai indikasi medis, dan secara garis besar dapat dikelompokkan menjadi 3 macam jenis pengobatan yaitu somatoterapi (badan) dengan tujuan untuk memberikan pengaruhpengaruh langsung yang berkaitan dengan badan, psikoterapi (jiwa) yang bertujuan untuk secara langsung memberikan pengaruhpengaruh yang berhubungan dengan kejiwaan, dan manipulasi lingkungan (lingkungan) yang bertujuan untuk memberikan pengaruh langsung pada lingkungan, baik lingkungan fisik maupun sosialnya (Yusuf, A.H., Rizky, F., dan Hanik, E.N, 2015).
Adanya hubungan antara pendidikan dengan tindakan pencarian pengobatan bagi ODGJ ini dikarenakan keluarga ODGJ yang memiliki pendidikan menengah selalu aktif untuk mencari informasi mengenai penyakit yang diderita keluarga, sehingga keluarga ODGJ cenderung untuk melakukan tindakan yang sesuai pada pencarian pengobatan ODGJ. Keluarga ODGJ yang memiliki pendidikan dasar, mencarikan pengobatan berdasarkan pengetahuan mengenai penyebab penyakit yang diyakini saja, sehingga keluarga ODGJ cenderung melakukan tindakan pengobatan yang tidak sesuai. Ternyata hasil penelitian ini tidak sesuai dengan penelitian sebelumnya yang menyatakan bahwa seorang yang berpendidikan tinggi mempunyai kecenderungan dalam melakukan pengobatan yang tidak sesuai dengan penyakitnya (Sya'diyah, H. 2016).

Hasil yang didapatkan peneliti ini sesuai dengan teori Lawrence green yang menyatakan bahwa tindakan seseorang akan dipengaruhi oleh pendidikan (Notoatmodjo,S., 2012). Ternyata hal tersebut didukung oleh peneliti sebelumnya yang menyatakan bahwa persentase yang tinggi pada keluarga yang memiliki pendidikan rendah akan mempengaruhi dukungan keluarga bagi orang dengan gangguan jiwa yaitu terutama pada pengetahuan dan perawatan penyakitnya (Nasriati, R, 2017). Selain itu tindakan seseorang juga dipengaruhi oleh informasi yang didapatkan dan juga pengalamannya (Mubarak, I.W, 2007).

\subsection{Hubungan Jenis Pekerjaan dengan Tindakan Pencarian Pengobatan Bagi ODGJ}

Pekerjaan akan mempengaruhi pengetahuan seseorang, lingkungan pekerjaan dapat menjadikan seseorang memperoleh pengalaman dan pengetahuan baik secara langsung maupun tidak langsung (Sya'diyah, H., 2016). Pada penelitian ini tidak terdapat hubungan pekerjaan dengan pencarian pengobatan bagi ODGJ. Hasil yang didapatkan peneliti ini sesuai dengan teori Lawrence green yang menyatakan bahwa tindakan seseorang akan dipengaruhi oleh jenis pekerjaan (Notoatmodjo,S., 2012). Seluruh keluarga ODGJ yang tidak bekerja 
mempunyai tindakan sesuai. Seseorang yang sibuk bekerja hanya memiliki waktu sedikit untuk memperoleh informasi karena waktu yang dimilikinya akan habis di lahan kerja, sedangkan masyarakat yang tidak bekerja memiliki waktu untuk memperoleh informasi (Sya'diyah, H, 2016).

Tindakan yang sesuai pada penelitian ini dikarenakan keluarga ODGJ yang tidak bekerja lebih banyak meluangkan waktunya untuk mencari informasi terkait penyakit yang diderita oleh keluarganya. Keluarga ODGJ yang di dalam lingkungan kerjanya terdapat orang-orang yang mempunyai pengetahuan baik terkait ODGJ maka pengetahuan keluarga ODGJ akan bertambah, sehingga keluarga ODGJ akan melakukan tindakan yang sesuai. Namun apabila keluarga ODGJ terlalu sibuk dengan pekerjaannya seperti sebagai petani, buruh, nelayan, wiraswasta maka keluarga ODGJ akan sedikit meluangkan waktunya untuk mencari informasi terkait gangguan jiwa yang dialami anggota keluarganya. Untuk mendapatkan tingkat penerimaan yang benar tentang kegawatan dan keuntungan tindakan pengobatan yang dilakukan, maka diperlukan isyarat-isyarat berupa faktor eksternal yaitu anjuran dari keluarga atau teman disekitar lingkungannya (Safitri, E.M., Luthviatin, N., dan Ririanty, M. 2016).

Hal lain yang menjadikan tidak adanya hubungan pekerjaan dengan tindakan pencarian pengobatan yaitu terkait biaya yang dikeluarkan untuk pengobatan ODGJ. Pengobatan yang dilakukan secara tradisional akan membutuhkan biaya yang lebih sedikit. Hal ini didukung oleh penelitian sebelumnya yang menyatakan bahwa pekerjaan tidak mempengaruhi seseorang dalam bertindak, hal ini dikarenakan tarif yang harus dilakukan untuk pengobatan profesional tergolong tinggi. Sehingga jika seseorang mendapatkan pengetahuan dari lingkungan kerjanya, belum tentu seseorang tersebut melakukan tindakan yang sesuai (Supriadi, 2014).

\subsection{Hubungan Pendapatan dengan Tindakan Pencarian Pengobatan Bagi ODGJ}

Pendapatan keluarga merupakan salah satu hal yang dapat mendukung pencarian pengobatan bagi orang dengan gangguan jiwa.
Keluarga dengan kelas pendapatan yang berlebih secara finansial akan mempunyai tingkat dukungan keluarga yang memadai (Nasriati, R, 2017). Hasil penelitian yang didapatkan oleh peneliti tidak terdapat hubungan antara keluarga yang memiliki pendapatan diatas UMR maupun keluarga yang memiliki pendapatan dibawah UMR. Hal ini tidak sesuai dengan teori Lawrence green yang menyatakan bahwa tindakan seseorang akan dipengaruhi oleh pendapatan seseorang (Notoatmodjo,S., 2012).

Keluarga yang mempunyai pendapatan diatas UMR akan cenderung untuk melakukan tindakan ke fasilitas pelayanan kesehatan. Hal tersebut dikarenakan biaya untuk berobat ke Rumah Sakit atau dokter praktik secara mandiri membutuhkan biaya yang tidak sedikit, yaitu mulai dari Rp.400.000 sampai dengan Rp. 1.000.000 dalam sekali pengobatan. Upah yang diterima keluarga dari ODGJ hampir semuanya dibawah UMR, dan penghasilan keluarga yang tinggi akan memberikan dukungan yang memadai bagi perawatan ODGJ, serta sebaliknya pendapatan keluarga yang rendah maka akan mempengaruhi perawatan ODGJ yang kurang memadai (Nasriati, R, 2017). Tidak adanya hubungan antara pendapatan dengan tindakan pencarian pengobatan dikarenakan keluarga akan berusaha mencarikan biaya untuk ODGJ yaitu berupa meminjam di bank ataupun di kerabat lainnya, selain itu pengobatan yang dilakukan di fasilitas pelayanan kesehatan (Puskesmas) dilakukan secara gratis. Pengobatan gratis tersebut didukung oleh kebijakan Gubernur Jatim Soekarwo yang membebaskan biaya pengobatan pasien gangguan jiwa mulai dari perawatan di Rumah Sakit Jiwa hingga di Puskesmas (Dinas Komunikasi dan Informatika Provinsi Jawa Timur, 2011).

\subsection{Hubungan Lama Sakit Anggota Keluarga dengan Tindakan Pencarian Pengobatan Bagi ODGJ}

Lama sakit yang diderita anggota keluarga keluarga ODGJ akan mengarahkan keluarga ODGJ untuk melakukan tindakan pencarian pengobatan bagi ODGJ. Lama sakit yang diderita ODGJ akan memberikan pengalaman dalam pencarian pengobatan bagi keluarga ODGJ (Hardiyanti, D., Usman, S., 
Yusuf, R., 2015). Pada penelitian ini tidak terdapat hubungan antara lama sakit anggota keluarga dengan pencarian pengobatan bagi ODGJ. Hal ini tidak sesuai dengan teori Lawrence green yang menyatakan bahwa tindakan seseorang akan dipengaruhi oleh lama sakit anggota keluarga (Notoatmodjo,S., 2012).

Keluarga ODGJ yang mempunyai ODGJ dengan lama sakit $>1$ tahun akan mencoba berbagai macam pengobatan yang diketahui. Dari pengobatan yang didapatkan tersebut, keluarga ODGJ cenderung untuk menunggu hasil dari pengobatannya. Sehingga keluarga ODGJ akan melakukan pengobatan medis jika dari mencoba pengobatan tersebut tidak didapatkan hasilnya. Keluarga ODGJ yang memiliki ODGJ dengan lama sakit $\leq 1$ tahun mempunyai tindakan sesuai, hal ini dikarenakan keluarga ODGJ telah mendapatkan informasi bahwa tetangga yang mempunyai gangguan jiwa sembuh setelah melakukan pengobatan ke Puskesmas dan dilakukan secara gratis. Sehingga keluarga ODGJ tersebut melakukan tindakan sesuai dan hanya beberapa kali melakukan pengobatan ke pengobatan non medis. Hasil penelitian yang dilakukan oleh peneliti sesuai dengan penelitian sebelumnya yang menyatakan bahwa keluarga yang mempunyai anggota keluarga menderita gangguan jiwa dengan lama sakit $>1$ tahun memiliki jenis pencarian pengobatan beragam daripada keluarga yang memiliki anggota keluarga dengan lama sakit $<1$ tahun (Hardiyanti, D., Usman, S., Yusuf, R. 2015). ODGJ yang mempunyai lama sakit lebih dari 1 tahun akan berusaha diobatkan ke pengobatan medis, karena keluarga telah melakukan berbagai hal dan mendapatkan hasil positif dari pengobatan medis.

\subsection{Hubungan Kekerabatan dengan Tindakan Pencarian Pengobatan Bagi Orang Dengan Gangguan Jiwa}

Hubungan kekerabatan yang dekat akan membuat keluarga merawat ODGJ. Rasa kasihan yang ada pada keluarga mendorong keluarga untuk melakukan pencarian pengobatan bagi ODGJ. Pada penelitian ini tidak didapatkan hubungan yang signifikan antara hubungan kekerabatan dengan tindakan pencarian pengobatan pada ODGJ. Hal ini tidak sesuai dengan teori Lawrence Green yang menyatakan bahwa tindakan seseorang akan dipengaruhi oleh hubungan kekerabatan yang dimiliki (Notoatmodjo,S., 2012). ODGJ yang mempunyai hubungan kekerabatan dari keluarga ODGJ sebagai ayah dan sebagai ibu mempunyai tindakan sesuai, hal ini karena seorang anak akan berupaya memberikan yang terbaik untuk kesembuhan orang tuanya. Keluarga akan merasa bersalah jika sebagai orang terdekat tidak berusaha mengobatkan ODGJ (Janardhana, N., Raghunandan, S., Naidu, D.M., Saraswathi, L., dan Seshan, V.,2015).

Hubungan kekerabatan yang dekat dengan ODGJ ini membuat keluarga ODGJ mempunyai tanggung jawab yang besar dalam merawat ODGJ. Namun walaupun demikian, tindakan yang dilakukan oleh keluarga ODGJ belum tentu sesuai. Hal ini dikarenakan keluarga ODGJ masih dalam tahap mencoba dalam pengobatan ODGJ. Keluarga ODGJ yang mempunyai hubungan kekerabatan sebagai orang tua dari ODGJ ini sebagian besar berusia lanjut, sehingga mereka mengalami keterbatasan dalam mendapatkan informasi. Informasi mengenai gangguan jiwa hanya didapatkan dari tetangga ataupun orang-orang terdekat dari keluarga ODGJ. Hal tersebut didukung oleh penelitian sebelumnya yaitu walaupun seseorang mempunyai hubungan kekerabatan yang dekat, namun seseorang tersebut minim dalam pengetahuannya, maka dia akan melakukan tindakan yang tidak sesuai (Janardhana, N., Raghunandan, S., Naidu, D.M., Saraswathi, L., dan Seshan, V. 2015.).

\subsection{Hubungan Tipe Keluarga dengan Tindakan Pencarian Pengobatan Bagi ODGJ}

Tipe keluarga yang ada pada ODGJ akan dapat memberikan pengaruh pada pengobatannya. Pada penelitian ini, tidak terdapat hubungan yang signifikan antara tipe keluarga dengan tindakan pencarian pengobatan bagi ODGJ. Hal ini tidak sesuai dengan teori Lawrence green yang menyatakan bahwa tindakan seseorang akan dipengaruhi oleh tipe keluarga yang dimiliki (Notoatmodjo,S., 2012). Keluarga yang mempunyai ODGJ dengan tipe keluarga inti mempunyai tindakan yang sesuai lebih banyak 
daripada ODGJ yang mempunyai keluarga besar.

Tindakan yang sesuai ini dikarenakan keluarga ODGJ yang memiliki keluarga inti akan lebih berusaha mencarikan pengobatan pada pelayanan kesehatan walaupun dengan biaya yang tidak sedikit. Hal ini dikarenakan keluarga ODGJ merasa beban yang ditanggung dalam satu keluarga tidak banyak sehingga harus diupayakan kesembuhan ODGJ walaupun membutuhkan biaya yang banyak. Keluarga ODGJ dengan tipe keluarga besar seringkali masih memikirkan terkait biaya yang harus dikeluarkan untuk pengobatan ODGJ karena keluarga ODGJ merasa kebutuhan yang ditanggung dalam satu keluarga tidak hanya untuk satu orang. Seseorang yang mempunyai tipe keluarga besar akan mudah dalam penyembuhannya, karena dalam proses pengobatannya ODGJ akan banyak dibantu oleh keluarga yang lainnya (Janardhana, N., Raghunandan, S., Naidu, D.M., Saraswathi, L., dan Seshan, V.,2015). Namun walaupun demikian seseorang yang mempunyai tipe keluarga inti seringkali tidak melakukan tindakan yang sesuai, dikarenakan pengetahuan yang kurang dan masalah biaya yang dihadapi.

\subsection{Hubungan Kepesertaan Jaminan Kesehatan Nasional dengan Tindakan Pencarian Pengobatan Bagi ODGJ}

Kepesertaan Jaminan Kesehatan Nasional merupakan program yang wajib diikuti oleh seluruh masyarakat Indonesia, untuk mencapai Universal Health Coverage (UHC) atau cakupan kesehatan menyeluruh bagi seluruh penduduk Indonesia pada 1 Januari 2019 mendatang (PP Nomor 12 Tahun 2013).

Pada penelitian ini tidak didapatkan hubungan kepesertaan Jaminan Kesehatan Nasional dengan tindakan pencarian pengobatan bagi ODGJ. Hasil yang didapatkan peneliti ini tidak sesuai dengan teori Lawrence green yang menyatakan bahwa tindakan seseorang akan dipengaruhi oleh Kepesertaan Jaminan Kesehatan Nasional (Notoatmodjo,S., 2012). Hal tersebut dikarenakan keluarga ODGJ yang mempunyai JKN ketika melakukan tindakan ke fasilitas pelayanan kesehatan tidak mengetahui cara memanfaatkan dan menggunakannya, sehingga pada akhirnya JKN tersebut tidak bisa digunakan untuk pelayanan berobat maupun konsultasi bagi ODGJ. Tidak diikutkannya ODGJ dalam kepesertaanJKN dikarenakan keluarga merasa kesulitan dalam mengurus persyaratan pendaftaran JKN. Selain itu keluarga merasa keberatan untuk membayarkan setiap bulannya, karena satu Kartu Keluarga (KK) ada yang terdiri lebih dari 5 orang sehingga keluarga merasa tidak mampu untuk membayarkan setiap bulannya dengan penghasilan yang didapatkannya. Keluarga ODGJ yang tidak setuju mengikuti JKN dikarenakan mereka merasa dirugikan apabila menjadi peserta JKN dan membayar iuran setiap bulannya seumur hidup tetapi tidak sakit atau jarang sakit dan uang tidak dikembalikan (Purwandari, S.I. 2015).

Tidak adanya hubungan antara kepesertaan Jaminan Kesehatan Nasional dengan tindakan pencarian pengobatan juga disebabkan pengobatan ODGJ gratis jika dilakukan di Puskesmas sehingga kepesertaan ODGJ dalam Jaminan Kesehatan Nasional tidak berpengaruh dalam tindakan pencarian pengobatannya. Pembebasan biaya untuk pengobatan ODGJ ini juga didukung oleh kebijakan Gubernur Jatim Soekarwo untuk menanggung semua biaya pasien gangguan jiwa. Mulai dari transportasi mengantarkan ke RSJ (Rumah Sakit Jiwa) hingga perawatan dan pengobatan (Dinas Komunikasi dan Informatika Provinsi Jawa Timur, 2011).

\section{Simpulan dan saran}

\subsection{Simpulan}

Tidak terdapat hubungan antara karakteristik keluarga ODGJ (usia), jenis kelamin, jenis pekerjaan, pendapatan, lama sakit, hubungan kekerabatan, tipe keluarga dengan, dan kepesertaan jaminan kesehatan nasional dengan tindakan pencarian pengobatan bagi ODGJ. Terdapat hubungan antara karakteristik keluarga ODGJ (pendidikan) dengan tindakan pencarian pengobatan bagi ODGJ $(p=0,035)$.

\subsection{Saran}

Perlu dilakukan penelitian dengan menggunakan metode kualitatif untuk mendapatkan hasil penelitian lebih mendalam. 


\section{Daftar Pustaka}

Dinas Komunikasi dan Informasi Provinsi Jawa Timur (2011) Jatim Tanggung Biaya Pasien Gangguan Jiwa. Available at: http://kominfo.jatimprov.go.id (Accessed: 4 April 2018).

Halida, N., Dewi, E. I., Rasni, H. (2016) 'Pengalaman Keluarga dalam Pemenuhan Kebutuhan Perawatan Diri pada Orang Dengan Gangguan Jiwa (ODGJ) dengan Pasung di Kecamatan Ambulu Kabupaten Jember', Jurnal Pustaka Kesehatan, 04(01), pp. 78-75.

Hardiyanti, D., Usman, S., Yusuf, R. (2015) 'Kemandirian Keluarga Dalam Merawat Anggota Keluarga Yang Mengalami Skizofrenia', Jurnal Ilmu Keperawatan, 3(2), pp. 172-182.

Janardhana, N., Raghunandan, S., Naidu, D.M., Saraswathi, L., dan Seshan, V. (2015) 'Care Giving of People With Severe Mental Illnes:An Indian Experience.', Indian Journal Of Psychological Medicine, 37(2), pp. 184-194.

Kemenkumham (2013) Peraturan Presiden Nomor 12 Tahun 2013 Tentang Jaminan Kesehatan.

Kementerian Kesehatan Republik Indonesia (2013) Riset Kesehatan Dasar 2013. Jakarta: Badan Penelitian dan Pengembangan Kesehatan Kementerian Kesehatan Republik Indonesia.

Kementerian Kesehatan Republik Indonesia (2014) Stop Stigma Dan Diskriminasi Terhadap Orang Dengan Gangguan Jiwa (ODGJ).available at: pkes.go.id./article/view/201410270011( accessed: 7 September2017)

Kemkumham (2014) Undang-Undang Nomor 18 Tahun 2014 tentang Kesehatan Jiwa

Lestari,W., dan Wardhani, Y. . (2014) 'Stigma Dan Penanganan Penderita Gangguan Jiwa Berat Yang Dipasung', Buletin
Penelitian Sistem Kesehatan, 17(2), pp. 157-166.

Nasriati, R. (2017) 'Stigma Dan Dukungan Keluarga Dalam Merawat Orang Dengan Gangguan Jiwa (ODGJ).', Jurnal Ilmiah Ilmu Ilmu Kesehatan, 15(1), pp. 56-65.

Notoatmodjo, S. (2012) Promosi Kesehatan dan Perilaku Kesehatan. Jakarta: Rineka Cipta.

Purwandari, S. I. (2015) 'Analisis Sikap Pekerja Informal Non PBI Yang Belum Terdaftar Program Jaminan Kesehatan Nasional (JKN) 2014 Di Kabupaten Brebes.', Unnes Journal of Public Health, 4(2), pp. 84-91.

Safitri, E.M., Luthviatin, N., dan Ririanty, M. (2016) 'Determinan Perilaku Pasien dalam Pengobatan Tradisional dengan Media Lintah (Studi Pada Pasien Terapi Lintah di Desa Rengel Kecamatan Rengel Kabupaten Tuban)', Jurnal Pustaka Kesehatan, 4(1), pp. 181-187.

Supriadi. (2014) Determinan Perilaku Pencarian Pengobatan Tradisional Masyarakat Urban Cengkareng Jakarta Barat Tahun 2014. Universitas Islam Negeri Syarif Hidayatullah Jakarta.

Sya'diyah, H. (2016) 'Studi Tingkat Pengetahuan Masyarakat Tentang Gangguan Jiwa Di Desa Banjar Kemantren Buduran Sidoarjo', Jurnal Ilmiah Kesehatan, 9(1), pp. 32-38.

Waskitho, A. P. (2015) Peran Keluarga Terhadap Proses Penyembuhan Pasien Perilaku Kekerasan di Panti Rehabilitasi Mental Wisma Budi Makarti Boyolali. Stikes Kusuma Husada Surakarta.

Yusuf, A.H., Rizky, F., dan H. and E.N. (2015) Buku Ajar Keperawatan Kesehatan Jiwa. Jakarta: Salemba Medika. 